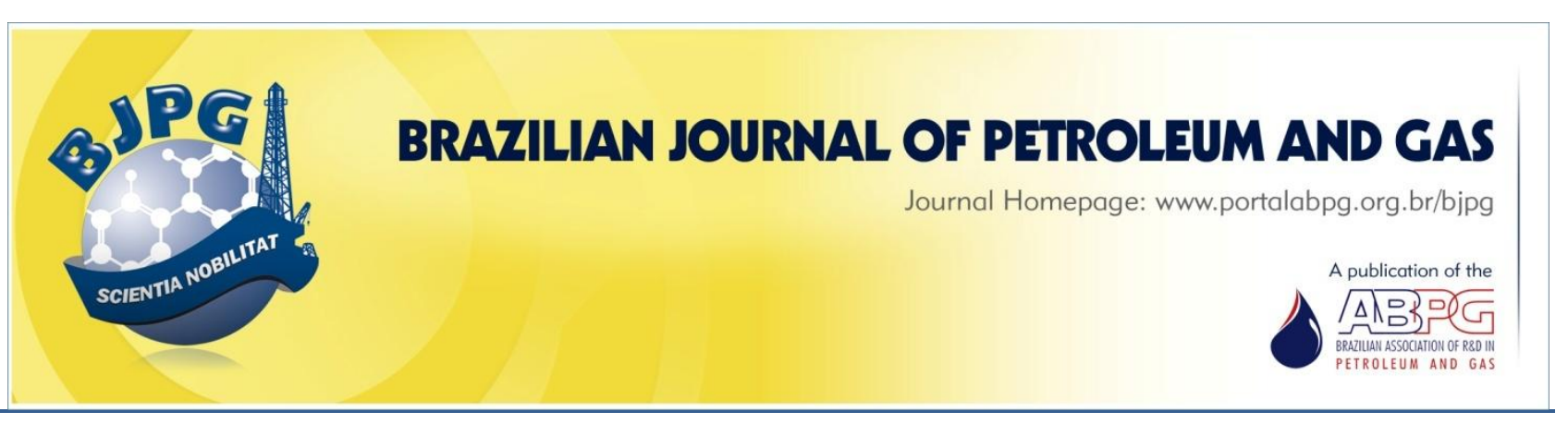

\title{
INFLUENCE OF GRANITE WASTE ON THE RHEOLOGICAL BEHAVIOR OF OIL WELL CEMENT SLURRIES
}

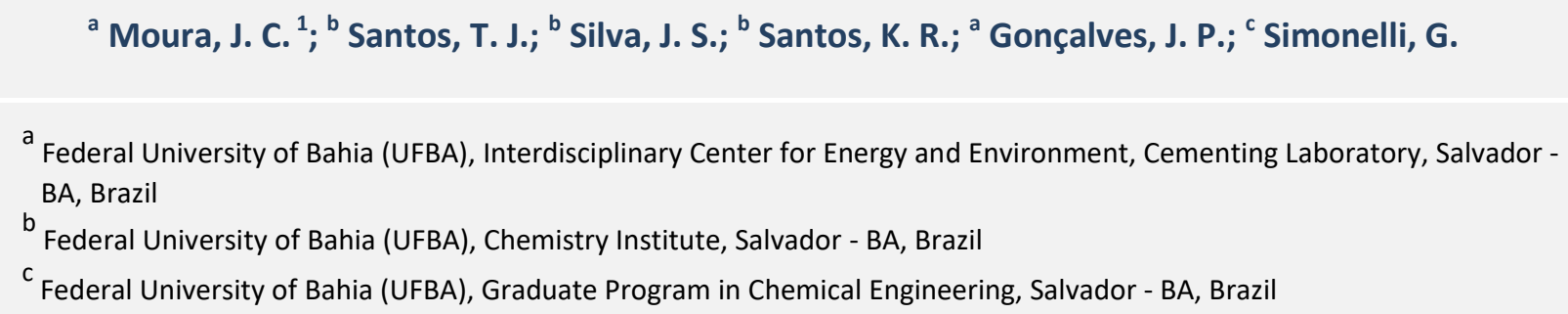

\section{ABSTRACT}

Several materials have been added to oil well cement slurries to improve their fresh and hardened properties. Many of these materials are industrial and agroindustrial wastes, and their use promotes sustainable development, avoiding their disposal in the environment. In this context, this study evaluates the rheological behaviour of oil well cement slurries containing granite cutting waste. The slurries were formulated with additions of $10 \%, 15 \%$, and $20 \%$ of granite waste (by weight of cement - BWOC), as well as reference slurry containing only water and Portland cement. The results revealed that slurries containing up to $20 \%$ of granite waste presented satisfactory rheological properties, proving their potential for application in oil well cementing operations. Moreover, the addition of $20 \%$ of granite waste was not considered detrimental to the compressive strength of the cement slurries.

\section{KEYWORDS}

oil well cement; granite cutting waste; rheology; cement slurry; industrial waste

\footnotetext{
${ }^{1}$ To whom all correspondence should be addressed.

Address: Federal University of Bahia (UFBA), Cementing Laboratory, Rua Antônio Jacobina de Brito, 63. Joaquim Romão. Jequié, BA, Brazil.

ZIP Code: 45.202-150 | Phone number: +55 (73) 99114-6389 | e-mail: jeu-costa@hotmail.com doi:10.5419/bjpg2019-0005
} 


\section{INTRODUCTION}

Cementing is one of the most important operations performed during the construction of oil and gas wells (El-Gamal et al., 2017). The cement is placed in the annulus between the casing and the formation surface to provide zonal isolation, support the casing, and protect it against corrosive fluids (Ahmed et al., 2009; Rodrigues et al., 2017; Sun et al., 2017). The importance of a proper slurry design for each application resides on the fact that, without appropriate zonal isolation, the well may never reach its full producing potential (Nelson, 1990).

The basic properties of the slurry should be evaluated and adjusted through laboratory testing to ensure a safe and effective cementing job. The rheological behaviour of cement slurries plays a key role among properties usually evaluated in cementing design. (Sun et al., 2017; Vlachou \& Piau, 2000). Rheological characterization is required to predict the flow regime in the annulus, the friction pressure drop, and the hydrostatic pressure during cementing (Nelson, 1990; Vlachou \& Piau, 2000).

In recent years, researchers have focused studying the properties of oil well cement slurries with the addition of different materials, evaluating how these materials influence, among other properties, the rheology of the slurries. Among the materials studied are metakaolin (Bu et al., 2016), nanosilica (Choolaei et al., 2012; Quercia et al., 2016), cellulose nanofibers (Sun et al., 2017), sugar

Table 1. Chemical composition and physical properties of the Special Portland cement.

\begin{tabular}{lr}
\hline Oxides & Mass (\%) \\
\hline $\mathrm{CaO}$ & 64.97 \\
$\mathrm{SiO}_{2}$ & 18.50 \\
$\mathrm{SO}_{3}$ & 4.20 \\
$\mathrm{Fe}_{2} \mathrm{O}_{3}$ & 4.01 \\
$\mathrm{Al}_{2} \mathrm{O}_{3}$ & 3.55 \\
$\mathrm{MgO}$ & 2.86 \\
$\mathrm{~K}_{2} \mathrm{O}$ & 0.88 \\
Others & 1.03 \\
\hline Density $\left(\mathrm{g} / \mathrm{cm}^{3}\right)$ & 3.195 \\
\hline Average diameter $(\mu \mathrm{m})$ & 26.18 \\
\hline
\end{tabular}

cane biomass waste (Anjos et al., 2013), and rice husk ash (Soares et al., 2015).

The use of industrial and agroindustrial wastes in cement slurries for oil wells is highly positive from the environmental point of view, since waste materials cause several problems to the environment when discarded in an inadequate way. In this context, the ornamental stone industry is becoming a concern for producing high amounts of waste. It is estimated that about $30 \%$ of the stone mass is disposed as waste during the cutting process (Elmoaty, 2013; Rajgor \& Pitroda, 2013). During this process, waste is produced in the form of mud. After drying, this mud gives rise to a fine powder, resulting in several environmental problems and damages to human health (Singh et al., 2016a). In addition to environmental problems, the transportation and disposal of this waste in landfills involves substantial costs. In this context, researchers have sought alternatives to incorporate these residues in other industrial processes, thus, reducing costs and the environmental impacts generated by the inappropriate waste disposal.

Recent researches present the possibility of reusing residual granite powder in the production of cement materials such as concrete, mortar, and cement slurries (Elmoaty, 2013; Sharma et al., 2017; Mashaly et al., 2018). Therefore, this study aims to evaluate the influence of the addition of granite powder waste on the rheological behaviour of cement slurries for oil wells cementation as a way to promote sustainable development.

\section{MATERIALS AND METHODS}

\subsection{Materials}

Special Portland cement was used in the formulation of the slurries. This Portland cement is specific for cementation of oil wells, classified according to NBR 9831 (ABNT, 2006). The chemical composition and physical properties of the cement are presented in Table 1.

The granite powder waste (GPW) used in this study is an industrial by-product generated during the cutting of granite blocks. The waste was provided by a local source. 


\subsection{Characterization of granite waste}

Before carrying out the analyses and formulating the slurries, the granite waste was ground to reduce their granulometry and eliminate clods. Grinding was performed in a Retsch PM-100 planetary ball mill for 5 minutes at $300 \mathrm{rpm}$.

The chemical composition of the granite powder waste was determined using X-ray fluorescence (XRF) technique. Pressed powder samples were analyzed on a Bruker S8-Tiger spectrometer, operated at $40 \mathrm{kV}$ and $30 \mathrm{~mA}$. The mineralogical characterization and identification of crystalline phases of the waste were performed using X-ray diffraction (XRD) technique. The XRD analyses were conducted on a Shimadzu XRD-6000 diffractometer using CuKa radiation, operated at $40 \mathrm{kV}$ and $30 \mathrm{~mA}$. Readings were taken in the range from $5^{\circ}$ to $60^{\circ}(2 \theta)$ at a rate of $0.5^{\circ} / \mathrm{min}$. The GPW density was determined by helium gas pycnometry, using the Micromeritics Accupyc II 1340 picnometer.

After grinding, the particle size distribution of the waste was performed by laser diffraction on a Malvern Mastersizer-3000 laser particle size analyzer. Differential thermal (DTA) and thermogravimetric (TG) analyses were carried out on a Shimadzu DTG $60 \mathrm{H}$ simultaneous analyzer under $50 \mathrm{ml} / \mathrm{min}$ of $\mathrm{N}_{2}$. The powdered sample was heated from $25^{\circ} \mathrm{C}$ to $1000{ }^{\circ} \mathrm{C}$, at a steady rate of 10 ${ }^{\circ} \mathrm{C} / \mathrm{min}$. Scanning electron microscopy (SEM) analyses were performed on the Hitachi S-3400N scanning electron microscope.

\subsection{Cement slurries formulation}

The oil well cement slurries were formulated with $10 \%, 15 \%$, and $20 \%$ granite powder waste (by weight of cement - BWOC), as well as standard slurry (STD), which contained only water and
Portland cement. Table 2 shows the composition of the slurries for each formulation. The slurry density was fixed at $15.6 \mathrm{lb} / \mathrm{gal}(1.87 \mathrm{~g} / \mathrm{cm} 3)$ in the fresh state. The slurries were mixed using a Chandler 3260 mixer, according to NBR 9831 (ABNT, 2006).

\subsection{Slurry conditioning}

Immediately after mixing, before the rheological testing, the slurries were conditioned in a Chandler 1200 atmospheric consistometer for a period of 20 minutes at a rotation of $(150 \pm 5) \mathrm{rpm}$, as recommended by NBR 9831 (ABNT, 2006). During this period, the slurries were heated to the test temperatures $\left(27^{\circ} \mathrm{C}\right.$ and $\left.39^{\circ} \mathrm{C}\right)$. For the tests at 27 ${ }^{\circ} \mathrm{C}$, the temperature was kept constant during the conditioning. For the tests at $39{ }^{\circ} \mathrm{C}$, the slurry was poured into the equipment at an initial temperature of $27{ }^{\circ} \mathrm{C}$, and heated at a constant rate until reaching the test temperature after 20 minutes of conditioning.

The temperature of $27^{\circ} \mathrm{C}$ was chosen because it is recommended by NBR 9831 (ABNT, 2006), thus allowing the comparison of the results obtained in the tests with the acceptance values specified by the standard. On the other hand, the temperature of $39{ }^{\circ} \mathrm{C}$ was chosen to simulate the bottom hole circulation temperature (BHCT) conditions for the surface phase of onshore oil wells in the northeast of Brazil. This temperature was established by computational simulation for a real well with a depth of $760 \mathrm{~m}$.

\subsection{Rheological evaluation}

The rheological properties of fresh slurries were evaluated by a Chandler 3530 viscometer. The tests were performed at the temperatures of $27^{\circ} \mathrm{C}$ and $39{ }^{\circ} \mathrm{C}$, which were maintained throughout the test by a heated cup assembly.

Table 2. Slurry compositions.

\begin{tabular}{cccccc}
\hline Mixes & GPW (\% BWOC) & Cement (g) & GPW (g) & Water (g) & $\begin{array}{c}\text { Water/cement } \\
\text { factor (W/C) }\end{array}$ \\
\hline STD & 0 & 761.11 & - & 360.93 & 0.47 \\
GPW10 & 10 & 694.95 & 69.50 & 357.59 & 0.51 \\
GPW15 & 15 & 666.01 & 99.90 & 356.12 & 0.53 \\
GPW20 & 20 & 639.38 & 127.88 & 354.78 & 0.55 \\
\hline
\end{tabular}


Table 3. Chemical composition of the granite waste (\% by weight).

\begin{tabular}{cccccccccccc}
\hline $\mathrm{SiO}_{2}$ & $\mathrm{CaO}$ & $\mathrm{Al}_{2} \mathrm{O}_{3}$ & $\mathrm{Fe}_{2} \mathrm{O}_{3}$ & $\mathrm{MgO}$ & $\mathrm{Na}_{2} \mathrm{O}$ & $\mathrm{K}_{2} \mathrm{O}$ & $\mathrm{P}_{2} \mathrm{O}_{5}$ & $\mathrm{TiO}_{2}$ & $\mathrm{SO}_{3}$ & $\mathrm{BaO}^{*}$ & Other $^{*}$ \\
\hline 46.81 & 16.77 & 13.96 & 7.97 & 4.22 & 3.22 & 2.57 & 1.83 & 1.65 & 0.27 & 0.23 & 0.50 \\
\hline
\end{tabular}

Note. *: $\mathrm{MnO}+\mathrm{SrO}+\mathrm{Cr}_{2} \mathrm{O}_{3}+\mathrm{Cl}+\mathrm{ZrO}_{2}+\mathrm{ZnO}+\mathrm{Rb}_{2} \mathrm{O}+\mathrm{CuO}$

The first reading was taken $60 \mathrm{~s}$ after continuous rotation at $300 \mathrm{rpm}$. Subsequent readings were performed at speeds of $200 \mathrm{rpm}$ and $100 \mathrm{rpm}$, at $20 \mathrm{~s}$ intervals. After reading at 100 $\mathrm{rpm}$, the speed was increased to $600 \mathrm{rpm}$ and kept constant for $60 \mathrm{~s}$. The viscometer was shut off for 10 seconds. Thereafter, the rotation was switched on at $3 \mathrm{rpm}$ and the maximum reading observed was recorded (10 s gel strength). The viscometer was shut off again for $10 \mathrm{~min}$. Thereafter the rotation was switched on at $3 \mathrm{rpm}$, and the maximum reading observed was recorded (10 min gel strength). The entire procedure was performed according to NBR 9831 (ABNT, 2006) recommendations.

\subsection{Analysis of rheological properties}

Viscometer raw data were used to calculate the shear rate and shear stress using Equations 1 and 2 (ABNT, 2006):

$\gamma=1.7023 \Omega$

$\tau=0.511 \theta$

Where:

$\gamma$ : Shear rate $\left(\mathrm{s}^{-1}\right)$

$\Omega$ : Viscometer rotational speed (rpm)

$\tau$ : Shear stress $(\mathrm{Pa})$

$\theta$ : Viscometer spring deflection reading (ㅇ)

Shear rate versus shear stress curves were plotted for each slurry evaluated. These curves are called flow curves, and they define the rheological behavior of the slurries. The Bingham plastic model was used to fit the curves. This model is used often to describe cement behavior, and it is defined by Equation 3 (Nelson, 1990):

$\tau=\tau_{o}+\mu \cdot \gamma$

Where:

$\tau o$ : Yield point $(\mathrm{Pa})$

$\mu$ : Plastic viscosity (Pa.s)
The rheological properties obtained for the slurries (plastic viscosity, yield point, $10 \mathrm{~s}$ gel strength, and $10 \mathrm{~min}$ gel strength) were compared with the limits established by NBR 9831 for the classification and acceptance of Special Portland cement.

\subsection{Compressive strength}

The compressive strength test was performed in triplicate according to the procedure recommended by NBR 9831 (ABNT, 2006). The tests were carried out using the Instron universal test machine, model 1000HDX, with loading ramps, as established by NBR 9831 (ABNT, 2006).

\section{RESULTS E DISCUSSION}

\subsection{Characterization of granite waste}

The chemical composition of the granite waste, determined by $\mathrm{X}$-ray fluorescence, is given in Table 3 , and its X-ray diffraction (XRD) pattern can be seen in Figure 1.

Table 3 shows that the granite residues consist mainly of silica $\left(\mathrm{SiO}_{2}\right)$, which represented $46.81 \%$ of the total weight. Other significant components included $\mathrm{CaO}(16.77 \%), \mathrm{Al}_{2} \mathrm{O}_{3}(13.96 \%)$, and $\mathrm{Fe}_{2} \mathrm{O}_{3}$ (7.97\%). It is worth mentioning that the chemical composition of GPW showed high $\mathrm{CaO}$ and $\mathrm{Fe}_{2} \mathrm{O}_{3}$ values because of the use of iron grit and lime as abrasive powder and lubricant agent, respectively, during the cutting process of ornamental stones (Menezes et al., 2009; Sadek et al., 2016).

The $\mathrm{X}$-ray diffraction analysis (Figure 1 ) shows that quartz (SiO2), muscovite $\left(\mathrm{KAl}_{2} \mathrm{Si}_{3} \mathrm{AlO}_{10}(\mathrm{OH})_{2}\right)$, sodium feldspar $\left(\mathrm{NaAlSi}_{3} \mathrm{O}_{8}\right)$, and potassium feldspar $\left(\mathrm{KAISi}_{3} \mathrm{O}_{8}\right)$ are the main mineral phases that compose the granite waste. The calcite $\left(\mathrm{CaCO}_{3}\right)$, identified in smaller proportions, does not have a significant influence on the performance of the cement slurry. Therefore, the presence of this phase in the waste is not negative for the slurry 


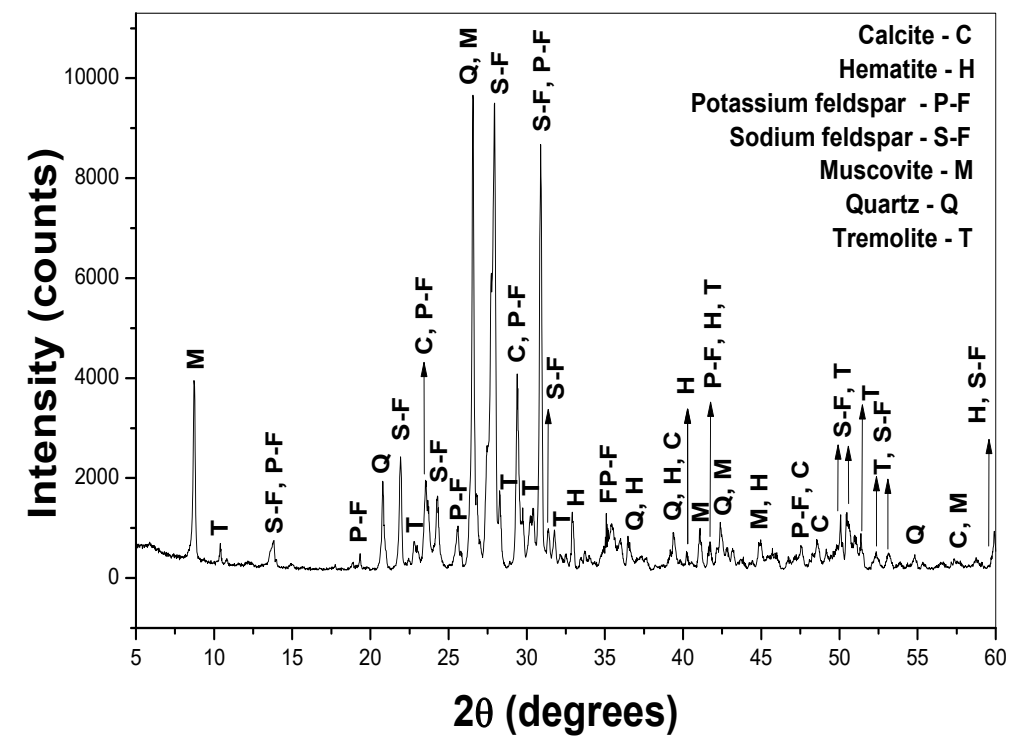

Figure 1. XRD diffraction pattern of granite powder waste.

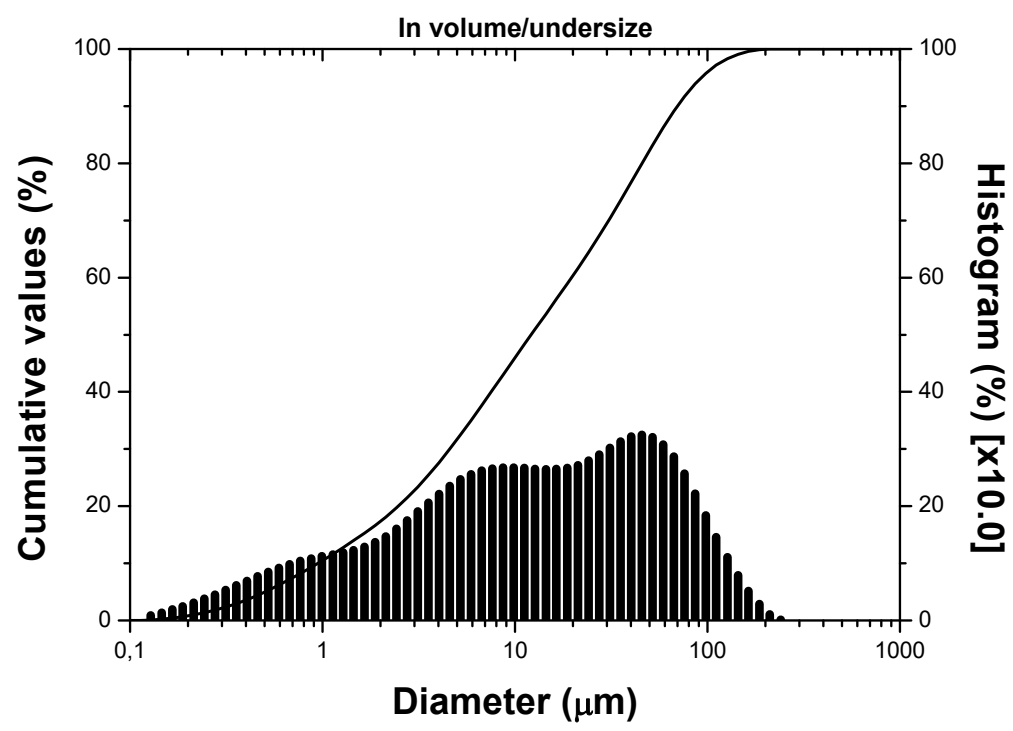

Figure 2. Particle size distribution of the granite waste.

performance (Singh et al., 2016b). The identified crystalline phases are in agreement with the results obtained from the chemical analysis.

The GPW density, obtained by pycnometry, was $2.8888 \mathrm{~g} / \mathrm{cm}^{3}$. Figure 2 shows the particle size distribution of the waste, determined by laser diffraction. The mean values of D10, D50, and D90 parameters were 1.0, 13.8, and $79.5 \mu \mathrm{m}$, respectively. The GPW average diameter was approximately $27.40 \mu \mathrm{m}$.

TG, DTG, and DTA curves of the granite waste are plotted in Figure 3. An endothermic peak is observed around $700{ }^{\circ} \mathrm{C}$. This peak is associated to carbonate decomposition (Acchar et al., 2006; Silva et al., 2005) and muscovite dehydroxylation (Menezes et al., 2009). The sodium and potassium feldspar mineralogical phases, present in the granite waste, have no effect on the mass loss, because they do not decompose between $25^{\circ} \mathrm{C}$ and $1000^{\circ} \mathrm{C}$ (Medina et al., 2017).

Figure 4 shows scanning electron microscopy (SEM) carried out on the granite waste sample. As one can observe, GPW presents particles with micrometric size and irregular morphology. The angular and rough shape is due to the cutting process of stone blocks. 


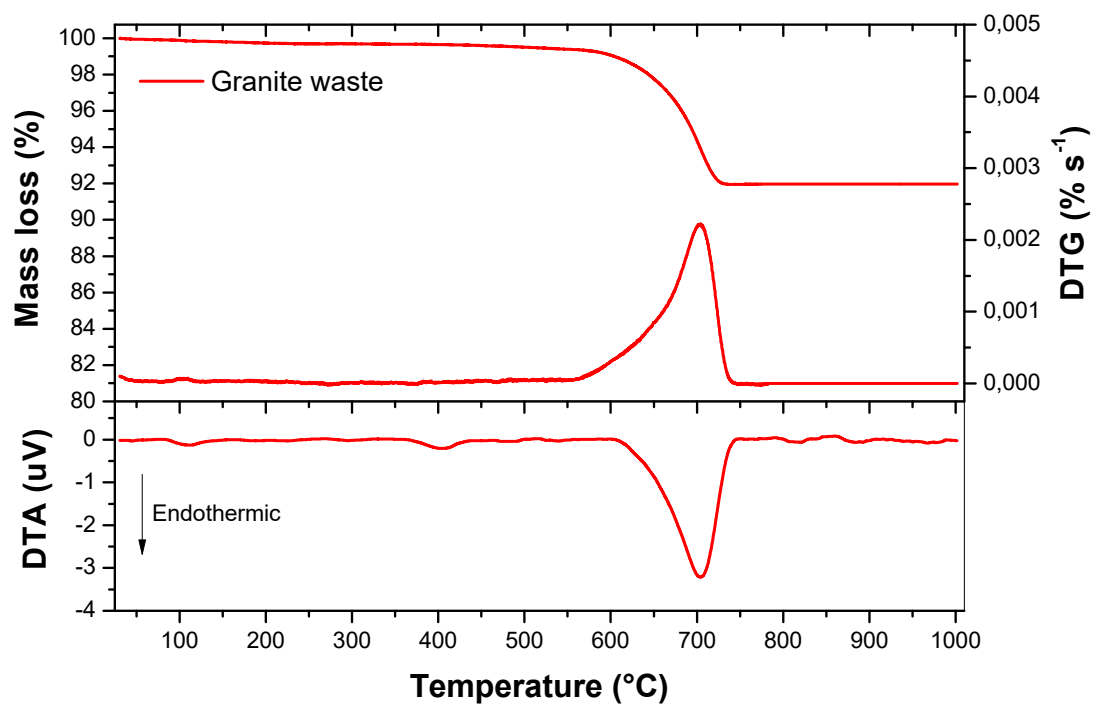

Figure 3. Differential thermal analysis (DTA), thermogravimetric analysis (TG), and differential thermogravimetric analysis (DTG) curves for GPW.
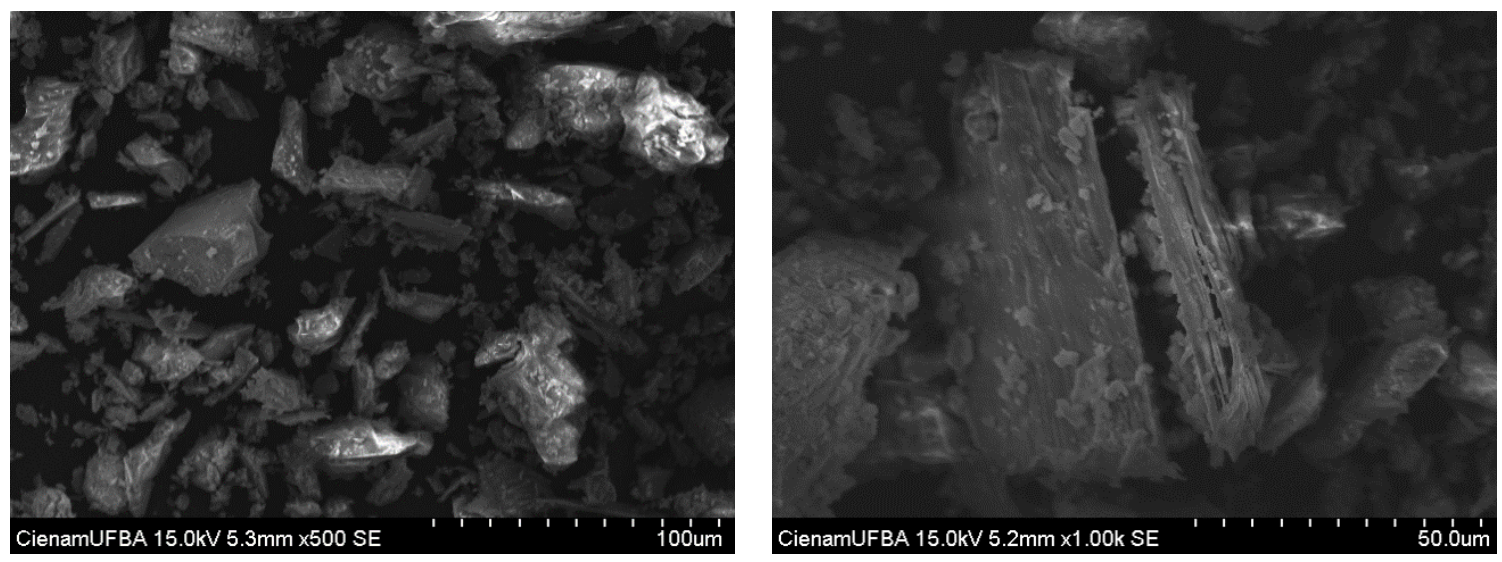

Figure 4. SEM images of granite waste particles.

\subsection{Rheological properties}

The readings recorded in the viscometer for the slurries formulated at temperatures of $27^{\circ} \mathrm{C}$ and 39 ${ }^{\circ} \mathrm{C}$ enabled the construction of their flow curves. The curves presented in Figure 5 show how the shear stress varies as a function of the shear rate applied for each slurry at $27{ }^{\circ} \mathrm{C}$ and $39{ }^{\circ} \mathrm{C}$. These curves define the rheological behavior of the slurries.

The correlation coefficients $\left(R^{2}\right)$ for the Bingham Plastic rheological model are shown in Table 4. All $\mathrm{R}^{2}$ values were close to 1 , indicating that the

Table 4. Correlation coefficient for the Bingham Plastic model.

\begin{tabular}{ccc}
\hline $\mathbf{G P W}$ & \multicolumn{2}{c}{$\mathbf{R}^{\mathbf{2}}$} \\
\cline { 2 - 3 } (\% Bwoc) & $\mathbf{2 7}^{\circ} \mathbf{C}$ & $\mathbf{3 9}{ }^{\circ} \mathbf{C}$ \\
\hline 0 & 0.9918 & 0.9865 \\
10 & 0.9970 & 0.9929 \\
15 & 0.9804 & 0.9979 \\
20 & 0.9774 & 0.9918 \\
\hline
\end{tabular}



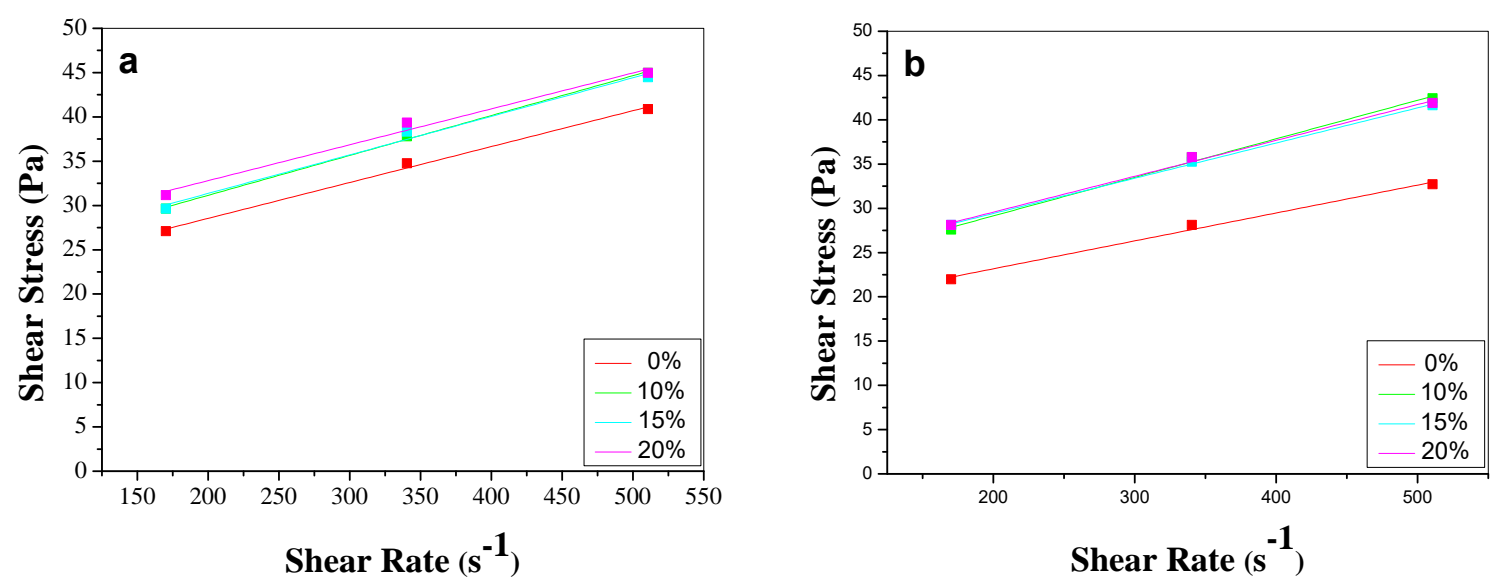

Figure 5. Flow curves of slurries at (a) $27^{\circ} \mathrm{C}$ and (b) $39^{\circ} \mathrm{C}$.
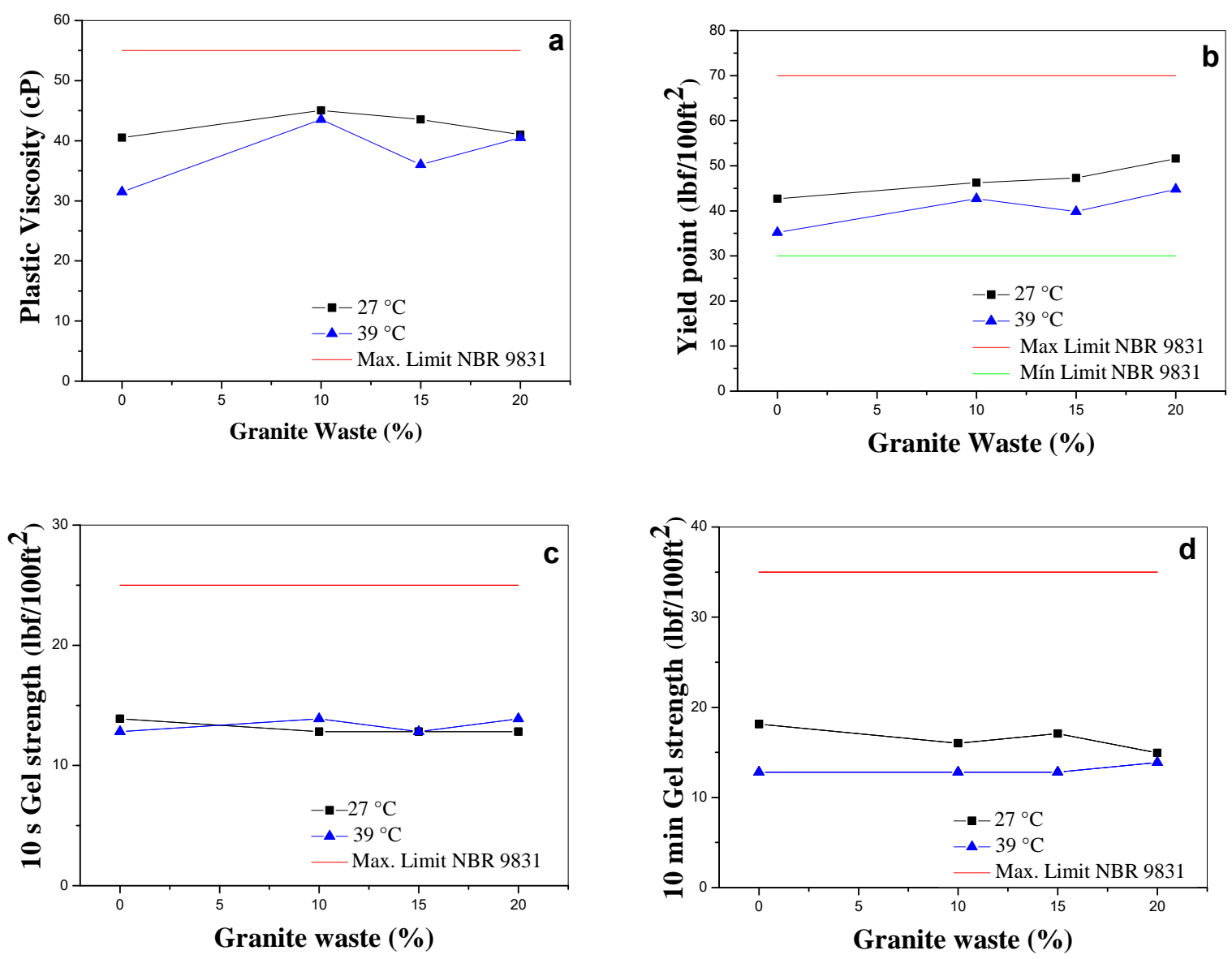

Figure 6. Rheological parameters of slurries at $27^{\circ} \mathrm{C}$ and $39^{\circ} \mathrm{C}$. (a) Plastic viscosity (cP); (b) Yield point (lbf/100ft ${ }^{2}$; (c) $10 \mathrm{~s}$ Gel strength (lbf/100ft $\left.{ }^{2}\right)$; and (d) $10 \mathrm{~min}$ Gel strength (lbf/100ft ${ }^{2}$ ).

Bingham model described the rheological behavior of the evaluated slurries satisfactorily.

A proper characterization of the cement slurry rheology is important to determine the flow regime and pressures during the cementing operation, ensuring that slurries can be mixed on the surface and placed in the well with minimal pressure drop (Nelson, 1990). In this context, Figure 6 shows the rheological properties evaluated for the slurries at $27^{\circ} \mathrm{C}$ and $39^{\circ} \mathrm{C}$. The limits established by NBR 9831 
are represented by green (minimum) and red (maximum) lines.

According to the results shown in Figure 6 (a and $b$ ), the rheological properties of the slurries with granite waste increased slightly compared to the ones found for standard slurry, based on the higher plastic viscosity and yield point, determined using the Bingham Plastic model. The increase observed in the rheological properties of the slurries with addition of the waste may be due to an association of factors. The first one is the angular and rough shape of the granite waste. This texture favors the anchoring of particles and increases the friction between them, contributing to their agglomeration and, consequently, making the slurry flow difficult (Miranda, 2008). Also, the particle size distribution of the waste, with a high content of fines, increases the water demand by increasing water absorption, leading to a high resistance to the slurries flow as more waste is added (Mashaly et al., 2018; Vijayalakshmi et al., 2013).

Although all the slurries with waste addition had higher plastic viscosity values than standard slurries, one can observe that the slurries with $15 \%$, and $20 \%$ of granite waste showed viscosity values lower than those found for slurries with $10 \%$ addition. This indicates that slurries with $15 \%$ and $20 \%$ residue had better workability.

The slurries evaluated at $39^{\circ} \mathrm{C}$ showed values of yield point and plastic viscosity slightly lower than those found at $27{ }^{\circ} \mathrm{C}$, indicating that the temperature decreased the rheological parameters of the slurries.

The $10 \mathrm{~s}$ gel strength and $10 \mathrm{~min}$ gel strength results shown in Figures $6 c$ and $6 d$, respectively, indicate that the addition of waste had no significant impact on the gelation of the slurries, since the values obtained for the reference slurry are practically the same as those obtained for the slurries with addition of granite waste.

The increase in temperature reduced the $10 \mathrm{~min}$ gel strength values. For the $10 \mathrm{~s}$ gel strength results, however, the effect of temperature was not significant, and similar values were found for the two temperatures evaluated.

All the parameters evaluated for the slurries with granite waste were within the limits established by standard NBR 9831, which proves that the slurries added with up to $20 \%$ of GPW meet the rheological requirements established for Special Portland cement. Therefore, according to the results, the granite waste does not cause considerable losses to the slurries, making its use in well cementing viable.

\subsection{Compressive strength}

We prepared six samples with $639.38 \mathrm{~g}$ of cement, $127.88 \mathrm{~g}$ of granite waste (20\% granite waste in relation to weight of cement), and 354.78 $\mathrm{g}$ of water. The density of the slurries was set at $15.6 \mathrm{lb} / \mathrm{gal}\left(1.87 \mathrm{~g} / \mathrm{cm}^{3}\right)$ in the fresh state. The samples were cured at $54{ }^{\circ} \mathrm{C}$ for 1 and 28 days (in triplicate). This temperature was chosen to simulate the static bottom-hole temperature of a $760 \mathrm{~m}$ onshore well located in the Northeast area of Brazil.

The one-day cured sample exhibited compressive strength of $3333 \pm 102$ psi. At 28 days, the compressive strength was $5139 \pm 76$ psi. According to Nelson (1990), adequate zonal isolation is guaranteed, in general rules, with a compressive strength of 1000 psi. Therefore, all the cement slurries achieved compressive strength at least three times greater than $1000 \mathrm{psi}$.

\section{CONCLUSIONS}

A new waste, originated from the cutting of granite stones, was studied in the formulation of cement slurries for oil wells. The rheological properties of the slurries with addition of the waste were evaluated according to Brazilian standard NBR 9831 (ABNT, 2006). The main conclusions of this study are:

- The Bingham Plastic model satisfactorily describes the rheological behavior of cement slurries with up to $20 \%$ granite waste;

- The tests confirmed that rheological properties (plastic viscosity, yield point, $10 \mathrm{~s}$ gel strength, and $10 \mathrm{~min}$ gel strength) of the slurries with up to $20 \%$ granite waste are in accordance with the limits established by NBR 9831; 
- The increase of the temperature of the tests to $39{ }^{\circ} \mathrm{C}$, simulating real well conditions, leads to small falls in most of the studied properties, except for the $10 \mathrm{~s}$ gel readings, which remained practically the same for both temperatures;

- The addition of granite waste was not considered detrimental to the application of the cement slurries, considering that they presented satisfactory resistances (superior to 3000 psi after $24 \mathrm{~h}$ ).

Finally, the use of granite waste in cement slurries for oil wells represents a viable alternative from a rheological point of view, according to NBR 9831, as well as being an economically interesting way to reduce the environmental impact generated by the improper destination of waste, converting it into a commercial product.

\section{REFERENCES}

ABNT, NBR 9831, 2006. Cimento Portland destinado à cimentação de poços petrolíferos Requisitos e métodos de ensaio. (in Portguese).

Acchar, W.; Vieira, F. A.; Hotza, D. Effect of marble and granite sludge in clay materials. Materials Science and Engineering: A, v. 419, n. 1-2, p. 306-309, 2006.

https://doi.org/10.1016/j.msea.2006.01.021

Ahmed, R. M.; Takach, N. E.; Khan, U. M.; Taoutaou, S.; James, S.; Saasen, A.; Godøy, R. Rheology of foamed cement. Cement and Concrete Research, v. 39, n. 4, p. 353-361, 2009.

https://doi.org/10.1016/j.cemconres.2008.12.004

Anjos, M. A. S.; Martinelli, A. E.; Melo, D. M. A.; Renovato, T.; Souza, P. D.; Freitas, J. C. Hydration of oil well cement containing sugarcane biomass waste as a function of curing temperature and pressure. Journal of Petroleum Science and Engineering, v. 109, p. 291-297, 2013.

https://doi.org/10.1016/i.petrol.2013.08.016

Bu, Y.; Du, J., Guo, S.; Liu, H.; Huang, C. Properties of oil well cement with high dosage of metakaolin. Construction and Building Materials, v. 112, p. 39-48, 2016.

https://doi.org/10.1016/i.conbuildmat.2016.02.173
Choolaei, M.; Rashidi, A. M.; Ardjmand, M.; Yadegari, A.; Soltanian, H. The effect of nanosilica on the physical properties of oil well cement. Materials Science and Engineering: A, v. 538, p. 288-294, 2012.

https://doi.org/10.1016/i.msea.2012.01.045

Elmoaty, A. E. M. A. Mechanical properties and corrosion resistance of concrete modified with granite dust. Construction and Building Materials, v. 47, p. 743-752, 2013.

https://doi.org/10.1016/i.conbuildmat.2013.05.054

El-Gamal, S. M. A.; Hashem, F. S.; Amin, M. S. Influence of carbon nanotubes, nanosilica and nanometakaolin on some morphologicalmechanical properties of oil well cement pastes subjected to elevated water curing temperature and regular room air curing temperature. Construction and Building Materials, v. 146, p. 531-546, 2017.

https://doi.org/10.1016/i.conbuildmat.2017.04.124

Mashaly, A. O.; Shalaby, B. N.; Rashwan, M. A. Performance of mortar and concrete incorporating granite sludge as cement replacement. Construction and Building Materials, v. 169, p. $800-818,2018$.

https://doi.org/10.1016/i.conbuildmat.2018.03.046

Medina, G.; Sáez del Bosque, I. F.; Frías, M.; Sánchez de Rojas, M. I.; Medina, C. Granite quarry waste as a future eco-efficient supplementary cementitious material (SCM): Scientific and technical considerations. Journal of Cleaner Production, v. 148, p. 467-476, 2017.

https://doi.org/10.1016/i.jclepro.2017.02.048

Menezes, R. R.; Farias Filho, J.; Ferreira, H. S.; Neves, G. A.; Ferreira, H. C. Reciclagem de resíduos da construção civil para a produção de argamassas (Granite sawing waste recycling for mortar production). Cerâmica, v. 55 , n. 335 , p. 263-270, 2009. (in Portuguese) https://doi.org/10.1590/S0366$\underline{69132009000300005}$

Miranda, C. R. Pastas de cimento de alta compacidade para poços de petróleo-Processo de formulação, propriedades reológicas, resistência mecânica e química. 291f. Tese de doutorado. Programa de Pós-Graduação em Ciência de Materiais, Instituto Militar de Engenharia, Rio de Janeiro, Brasil, 2008. (in Portuguese). 
Nelson, E. B. Well Cementing. Sugar Land. Texas: Dowell Schlumberger Educational Service, 1990.

Quercia, G.; Brouwers, H. J. H.; Garnier, A.; Luke, $K$. Influence of olivine nano-silica on hydration and performance of oil-well cement slurries. Materials \& Design, v. 96, p. 162-170, 2016.

https://doi.org/10.1016/i.matdes.2016.02.001

Rajgor, M.B.; Pitroda, J. A study of utilization aspect of stone waste in Indian context. International Journal of Global Research Analysis, v. 2, n. 1, 2013.

Rodrigues, E. C.; de Andrade Silva, F.; de Miranda, C. R.; de Sa Cavalcante, G. M.; de Souza Mendes, P. R. An appraisal of procedures to determine the flow curve of cement slurries. Journal of Petroleum Science and Engineering, v. 159, p. 617-623, 2017. https://doi.org/10.1016/i.petrol.2017.09.053

Sadek, D. M.; El-Attar, M. M.; Ali, H. A. Reusing of marble and granite powders in self-compacting concrete for sustainable development. Journal of Cleaner Production, v. 121, p. 19-32, 2016. https://doi.org/10.1016/i.jclepro.2016.02.044

Sharma, N. K.; Kumar, P.; Kumar, S.; Thomas, B. S.; Gupta, R. C. Properties of concrete containing polished granite waste as partial substitution of coarse aggregate. Construction and Building Materials, v. 151, p. 158-163, 2017. https://doi.org/10.1016/i.conbuildmat.2017.06.081

Silva, J. B.; Hotza, D.; Segadães, A. M.; Acchar, $W$. Incorporação de lama de mármore e granito em massas argilosas (Incorporation of marble and granite sludge in clay materials). Cerâmica, v. 51, n. 320 , p. 325-330, 2005. (in Portuguese) https://doi.org/10.1590/S0366-69132005000400004
Singh, S.; Nagar, R.; Agrawal, V. Performance of granite cutting waste concrete under adverse exposure conditions. Journal of Cleaner Production, v. 127, p. 172-182, $2016 a$. https://doi.org/10.1016/i.jclepro.2016.04.034

Singh, S.; Khan, S.; Khandelwal, R.; Chugh, A.; Nagar, R., Sarbjeet et al. Performance of sustainable concrete containing granite cutting waste. Journal of Cleaner Production, v. 119, p. 8698, 2016b.

https://doi.org/10.1016/i.jclepro.2016.02.008

Soares, L. W.; Braga, R. M.; Freitas, J. C.; Ventura, R. A.; Pereira, D. S.; Melo, D. M. The effect of rice husk ash as pozzolan in addition to cement Portland class $\mathrm{G}$ for oil well cementing. Journal of Petroleum Science and Engineering, v. 131, p. 8085, 2015. https://doi.org/10.1016/i.petrol.2015.04.009

Sun, X.; Wu, Q.; Zhang, J.; Qing, Y.; Wu, Y.; Lee, S. Rheology, curing temperature and mechanical performance of oil well cement: Combined effect of cellulose nanofibers and graphene nanoplatelets. Materials \& Design, v. 114, p. 92-101, 2017. https://doi.org/10.1016/j.matdes.2016.10.050

Vijayalakshmi, M.; Sekar, A. S. S.; Ganesh Prabhu, G. Strength and durability properties of concrete made with granite industry waste. Construction and Building Materials, v. 46, p. 1-7, 2013.

https://doi.org/10.1016/j.conbuildmat.2013.04.018

Vlachou, V.; Piau, J. M. A new tool for the rheometric study of oil well cement slurries and other settling suspensions. Cement and Concrete Research, v. 30, n. 10, p. 1551-1557, 2000. https://doi.org/10.1016/s0008-8846(00)00378-1 